\title{
Trace element intakes of women
}

\author{
BY ROSALIND S. GIBSON AND CINDY A. SCYTHES \\ Applied Human Nutrition, Department of Family Studies, University of Guelph, Guelph, \\ Ontario, Canada
}

(Received 19 August 1981 - Accepted 30 March 1982)

1. Energy, protein, zinc, copper, manganese, selenium and dietary fibre intakes of 100 pre-menopausal women (mean age $30.0 \pm 6 \cdot 1$ years) from a university community, and consuming self-selected diets, were calculated using $3 \mathrm{~d}$ dietary records and food composition values. Subjects also collected a $24 \mathrm{~h}$ food composite during the $3 \mathrm{~d}$ record period for analysis of $\mathrm{Zn}, \mathrm{Cu}$ and $\mathrm{Mn}$ by atomic absorption spectrophotometry. Daily analysed intakes were compared with those calculated from the corresponding record day.

2. Mean daily calculated intakes of energy, protein, $\mathrm{Zn}, \mathrm{Cu}, \mathrm{Mn}$, Se and dietary fibre were $7.54 \pm 1.61 \mathrm{MJ}$, $74 \pm 18$ g protein, $10 \cdot 1 \pm 3.3 \mathrm{mg} \mathrm{Zn}, 1.9 \pm 0.6 \mathrm{mg} \mathrm{Cu}, 3 \cdot 1 \pm 1.5 \mathrm{mg} \mathrm{Mn}, 131 \pm 53 \mu \mathrm{g} \mathrm{Se}, 19 \cdot 4 \pm 6 \cdot 6 \mathrm{~g}$ dietary fibre.

3. Major food sources for each of the trace elements were $(\%): \mathrm{Zn}$ meat + substitutes 43 , dairy products 23.7 ; $\mathrm{Cu}$ breads and cereals 22 , vegetables 21 ; Mn breads and cereals 47 , fruits 12 ; Se meat + substitutes 38 , breads and cereals 30 .

4. Highly significant correlations $(P=0.001)$ were noted for analysed intakes of $\mathrm{Zn}, \mathrm{Cu}$ and $\mathrm{Mn}$ and those calculated from the corresponding record day. Mean calculated intakes were higher $(\%)$ : $\mathrm{Zn} \mathrm{138,Cu} \mathrm{142,} \mathrm{Mn} \mathrm{121,}$ than corresponding mean analysed intakes $(P=0.01)$. However, the mean nutrient densities $(\mathrm{mg} / \mathrm{MJ})$ were comparable: $\mathrm{Zn}$ analysed 1.2 , calculated $1.4 ; \mathrm{Cu}$ analysed $0 \cdot 2$, calculated $0 \cdot 2 ; \mathrm{Mn}$ analysed $0 \cdot 4$, calculated $0 \cdot 4$.

5. All subjects met the Canadian Dietary Standard (CDS) recommended level for $\mathrm{Cu}$ but $48 \%$ received less than the CDS for $\mathrm{Zn}, 6 \%$ obtaining less than two-thirds of this recommended level. Daily $\mathrm{Mn}$ and Se intakes were similar to recent values for North American diets.

Recent advances in food production and processing have led to significant changes in the trace element content of foods (Schroeder, 1971). The increasing use of more highly refined foods and food analogues has led to a reduction of copper, zinc, manganese and chromium intakes, and nutritional deficiency states for some of these trace elements have been reported in certain population groups (Levine et al. 1968; Hambidge et al. 1972; Klevay et al. 1979).

Clearly, it is important to monitor periodically the trace element content of human diets to assess whether existing dietary trace element recommendations are being met or exceeded, and to assist in establishing dietary recommendations for some of the trace elements.

The purpose of this study was to determine the $\mathrm{Zn}, \mathrm{Cu}, \mathrm{Mn}$, Se and dietary fibre intakes of a group of Canadian pre-menopausal women consuming self-selected diets. Dietary trace element intakes were calculated from $3 \mathrm{~d}$ food records using food composition values and by chemical analysis of a $1 \mathrm{~d}$ food composite collected during the $3 \mathrm{~d}$ record period.

\section{EX PER IMEN T A L}

Daily trace element intakes from dietary records

Pre-menopausal Canadian women (100; mean age $30 \pm 6 \cdot 1$ years) from a university community and consuming self-selected diets, participated in the study. Consent was obtained from the subjects after the nature of the study had been fully explained to them. The study protocol was approved by the Human Ethics Committee of the University of Guelph. Dietary information was collected using dietary records completed by the subjects in their own homes during three consecutive weekdays. Subjects recorded all foods and beverages consumed (including drinking water), in household measures and provided recipes for all prepared food items. Dietary records were checked on completion by a nutritionist. Daily intakes of energy, protein, $\mathrm{Cu}, \mathrm{Zn}, \mathrm{Mn}$, Se and dietary fibre were 


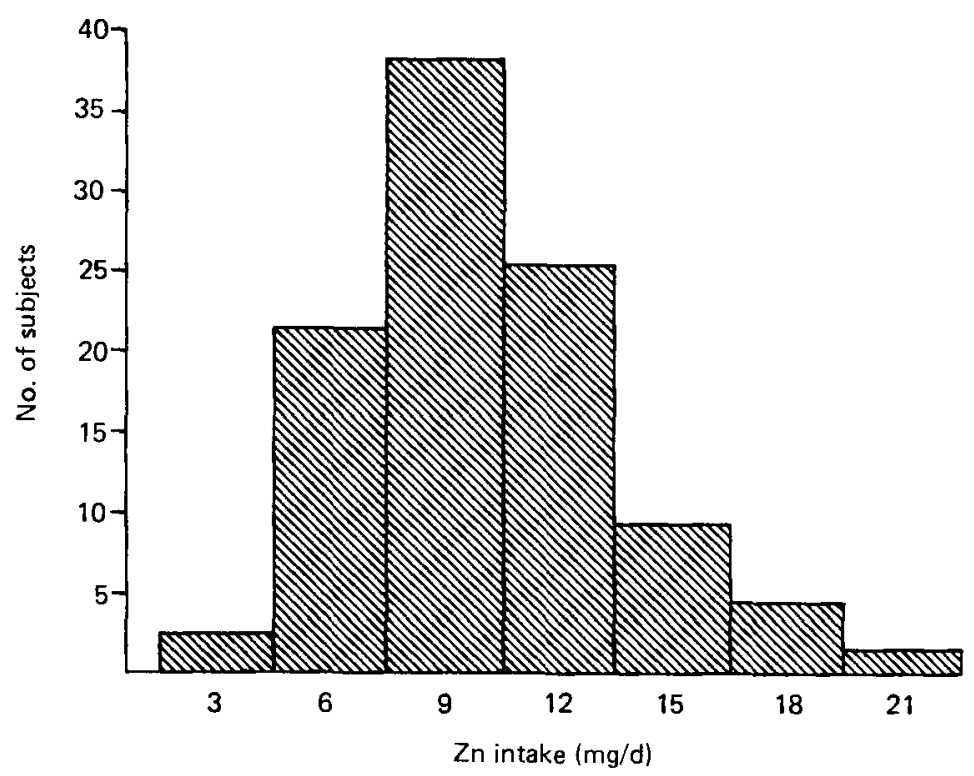

Fig. 1. Daily $\mathrm{Zn}$ intakes. $\bar{x}=10 \cdot 1, \mathrm{SD}=3 \cdot 3, n=100$.

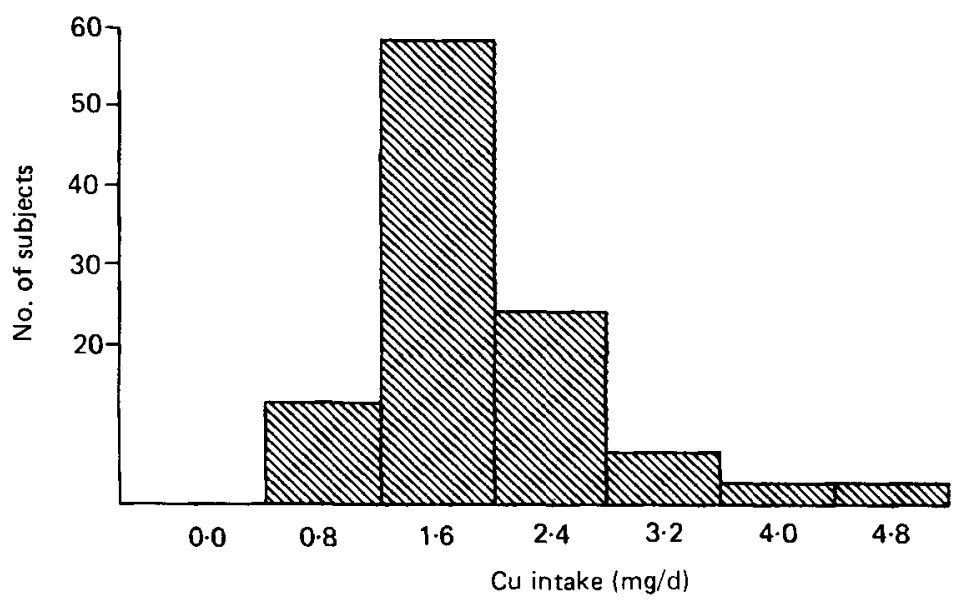

Fig. 2. Daily $\mathrm{Cu}$ intakes. $\bar{x}=1 \cdot 9, \mathrm{SD}=0 \cdot 6, n=100$.

calculated using the appropriate values for foods obtained from company product information, food composition tables (Agriculture Handbook, 1976, 1977, $1979 a, b$, $1980 a, b)$ and the literature (Morris \& Levander, 1970; Schlettwein-Gsell \& MommsenStraub, 1971 a, b, 1972; Arthur, 1972; Meiners et al. 1976; Southgate et al. 1976; Allen et al. 1977; Ganapathy et al. 1978; Freeland-Graves et al. 1980). Foodstuffs were divided into food groups to determine the most important sources for each of the trace elements investigated.

\section{Food composite collection and laboratory analysis}

During one of the three record days, each subject collected a duplicate portion of all foods and beverages consumed, including drinking water, in acid-washed polyethylene bags and jugs with non-metal lids respectively. 
Table 1. Mean calculated daily intakes of energy, protein, trace elements and dietary fibre by Canadian women

\begin{tabular}{lcc}
\hline \hline & Mean & SD \\
\hline Energy (MJ) & $7 \cdot 54$ & $1 \cdot 61$ \\
Protein (g) & $73 \cdot 8$ & $18 \cdot 2$ \\
Zn (mg) & $10 \cdot 1$ & $3 \cdot 3$ \\
Cu (mg) & 1.9 & 0.6 \\
Mn (mg) & $3 \cdot 1$ & $1 \cdot 5$ \\
Se $(\mu \mathrm{g})$ & 131 & 53.4 \\
Dietary fibre (g) & 19.4 & 6.6 \\
\hline
\end{tabular}

Food composites were returned to the laboratory and homogenized in a large stainless steel Waring Blendor (model no. CB5) coated with Teflon. To check for possible trace element contamination in this homogenization step, distilled deionized water was treated in the same manner as the food composite. No detectable $\mathrm{Cu}, \mathrm{Zn}$ or $\mathrm{Mn}$ were found. Beverages were combined gradually with the solid food items during the blending to produce a single homogenous sample.

After measuring the volume of the total homogenate, portions were poured immediately into three acid-washed polyethylene containers and frozen at $-17^{\circ}$ for retrospective analysis. After thawing, each of these three sub-samples were recombined and blended before removal of a $25 \mathrm{ml}$ portion using an acid-washed pipette. These portions were dried in acid-washed Pyrex beakers at $105^{\circ}$ to remove moisture and then ashed in a muffle furnace for $24-48 \mathrm{~h}$ at $450^{\circ}$. The ash was dissolved in $10 \mathrm{ml} 6 \mathrm{M}$-hydrochloric acid and analysed for $\mathrm{Zn}, \mathrm{Cu}$ and $\mathrm{Mn}$ by established atomic absorption procedures using a Perkin Elmer AA spectrophotometer (model 372). Replicates of one $24 \mathrm{~h}$ food composite were analysed to check on the homogenity of the portions removed from the food composite and the reproducibility of the method. Mean $( \pm \mathrm{SD})$ concentrations $(\mu \mathrm{g} / \mathrm{g})$ for four replicates of the

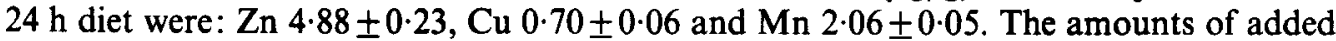
$\mathrm{Zn}, \mathrm{Cu}$ and $\mathrm{Mn}$ recovered were also determined at regular intervals. The mean percentages of recovery for $\mathrm{Zn}, \mathrm{Cu}$ and $\mathrm{Mn}$ were $94 \cdot 7 \pm 0 \cdot 3,95 \cdot 2 \pm 0.03$ and $94 \cdot 8 \pm 0 \cdot 3$ respectively. The accuracy of the method was studied by analysing Orchard Leaves Standard Reference Material no. 1571, National Bureau of Standards (NBS). Mean $( \pm \mathrm{SD})$ values $(\mu \mathrm{g} / \mathrm{g})$ for three replicates were: $\mathrm{Zn} 25 \cdot 3 \pm 2 \cdot 2, \mathrm{Cu} 13 \cdot 5 \pm 0 \cdot 2$ and $\mathrm{Mn} 91 \cdot 7 \pm 4$. Certified NBS mean values $(\mu \mathrm{g} / \mathrm{g})$ were: $\mathrm{Zn} 25 \pm 3, \mathrm{Cu} 12 \pm 1$ and $\mathrm{Mn} 91 \pm 4$. Analysed intakes were compared with those calculated from the corresponding record day using the paired Student's $t$ test.

\section{RESULTS}

\section{Calculated daily trace element intakes}

The calculated mean daily energy, protein, $\mathrm{Zn}, \mathrm{Cu}, \mathrm{Mn}, \mathrm{Se}$ and dietary fibre intakes are presented in Table 1. Frequency distributions of the daily trace element intakes are shown in Figs. 1-4. Zn intakes ranged from 4.1 to $21.7 \mathrm{mg} / \mathrm{d}$, with a mean value of $10.1 \mathrm{mg} / \mathrm{d}$, slightly above the Canadian Dietary Standard (CDS) recommendation of $9 \mathrm{mg} / \mathrm{d}$ (Department of Health \& Welfare Canada, 1975) but below the US Recommeneded Dietary Allowance (RDA) of $15 \mathrm{mg} / \mathrm{d}$ (National Research Council, Food \& Nutrition Board, 1980). Of the subjects, 48 and $91 \%$ failed to meet the CDS and RDA for Zn respectively, with 6 and $55 \%$ receiving intakes of less than two-thirds of these recommended levels.

All subjects met the current CDS estimated $\mathrm{Cu}$ requirement $(0.2 \mathrm{mg} / \mathrm{MJ})$ although $69 \%$ received intakes below the RDA safe and adequate level $(2-3 \mathrm{mg} / \mathrm{d})$ and $5 \%$ had intakes above $3 \mathrm{mg} / \mathrm{d}$. 


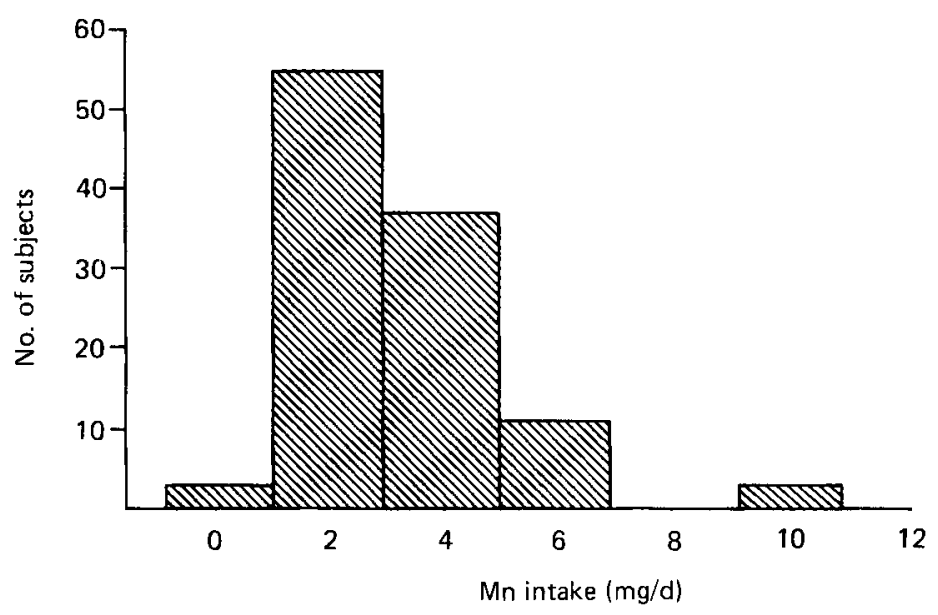

Fig. 3. Daily $\mathrm{Mn}$ intakes. $\bar{x}=3 \cdot 1, \mathrm{SD}=1 \cdot 5, n=100$.

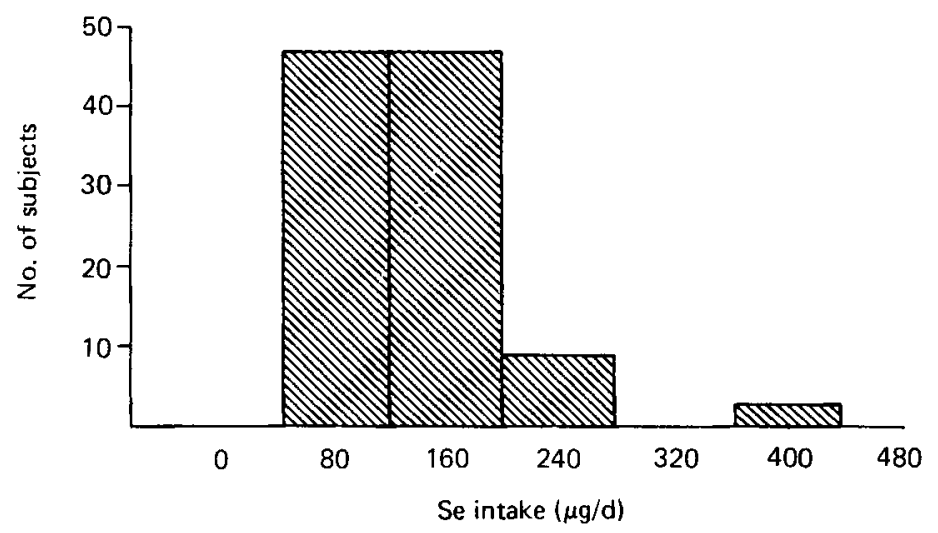

Fig. 4. Daily Se intakes. $\bar{x}=131, \mathrm{SD}=53 \cdot 4, n=100$.

Daily $\mathrm{Mn}$ intakes ranged from 0.7 to $10.8 \mathrm{mg} / \mathrm{d}$ with a mean daily intake of $3.1 \mathrm{mg} / \mathrm{d}$. A CDS recommendation has not been established for Mn and the RDA gives an estimated safe and adequate intake level of $2.5-5.0 \mathrm{mg} / \mathrm{d}$. Of the subjects, $37 \%$ received $\mathrm{Mn}$ intakes below this suggested safe limit and $10 \%$ exceeded this range.

Similarly, there is no CDS recommendation for Se. None of the subjects received less than the lower limit of the RDA safe and adequate level $(50 \mu \mathrm{g} / \mathrm{d})$ but nine of the subjects received intakes above the upper limit $(200 \mu \mathrm{g} / \mathrm{d})$ of this range.

The percentage contribution of six food groups to the daily trace element intakes are given in Table 2. Major food sources of both dietary $\mathrm{Zn}$ and Se were meat plus substitutes (includes legumes and soya-bean products), providing 43 and $38 \%$ respectively. In contrast, bread and cereals were the most important dietary sources of $\mathrm{Cu}(22 \%)$ and $\mathrm{Mn}(47 \%)$.

\section{Analysed $\mathrm{Zn}, \mathrm{Cu}$ and $\mathrm{Mn}$ intakes}

Table 3 compares the mean daily intakes of $\mathrm{Zn}, \mathrm{Cu}$ and $\mathrm{Mn}$ derived from laboratory analysis of the $1 \mathrm{~d}$ food composites with mean values obtained from calculation of the corresponding record day. As might be expected, highly significant positive correlations 
Table 2. Mean percentage contribution of six food groups to mean $\mathrm{Zn}, \mathrm{Cu}, \mathrm{Mn}$ and $\mathrm{Se}$ intakes of Canadian women

\begin{tabular}{lrrrrr}
\hline \multicolumn{1}{c}{ Food group } & $\mathrm{Zn}$ & $\mathrm{Cu}$ & $\mathrm{Mn}$ & $\mathrm{Se}$ \\
\hline Milk and milk products & $23 \cdot 7$ & $4 \cdot 5$ & $2 \cdot 1$ & $9 \cdot 2$ \\
Meat and substitutes & $43 \cdot 0$ & $16 \cdot 8$ & $7 \cdot 9$ & $38 \cdot 0$ \\
Vegetables & $9 \cdot 0$ & $21 \cdot 1$ & $6 \cdot 3$ & $7 \cdot 9$ \\
Fruit & $3 \cdot 5$ & $14 \cdot 7$ & $12 \cdot 0$ & $5 \cdot 3$ \\
Bread and cereals & $19 \cdot 0$ & $22 \cdot 0$ & $47 \cdot 0$ & $30 \cdot 0$ \\
& Fats, sugars, & $1 \cdot 7$ & $20 \cdot 7$ & $24 \cdot 6$ & $9 \cdot 4$ \\
beverages, alcohol & & & & \\
\hline
\end{tabular}

Table 3. Mean intakes $(m g / d)$ of $\mathrm{Zn}, \mathrm{Cu}$ and $\mathrm{Mn}$ of Canadian women determined by chemical analysis and calculation

\begin{tabular}{|c|c|c|c|c|}
\hline & \multicolumn{2}{|c|}{ Analysed } & \multicolumn{2}{|c|}{ Calculated } \\
\hline & Mean & $\mathrm{SD}$ & Mean & SD \\
\hline $\mathrm{Zn}$ & $7 \cdot 3$ & 3.0 & $10 \cdot 1$ & $4 \cdot 9^{*}$ \\
\hline $\mathrm{Cu}$ & 1.2 & 0.5 & 1.7 & $0.7^{*}$ \\
\hline $\mathrm{Mn}$ & 2.4 & $1 \cdot 1$ & 2.9 & $1.4^{*}$ \\
\hline
\end{tabular}

$* P<0.0001$.

were noted for the analysed trace element intakes and those obtained by calculation $(P=0.001)$. The calculated intakes of $\mathrm{Zn}, \mathrm{Cu}$ and $\mathrm{Mn}$ were 138,142 , and $121 \%$ higher than the analysed values respectively, and these differences were statistically significant $(P<0.0001)$. However, the ratios of the mean of each trace element per MJ of total dietary energy (i.e. mean nutrient density) obtained from chemical analysis of the $1 \mathrm{~d}$ food composite and by calculation of the corresponding record day were comparable: $\mathrm{Zn}$ analysed $1.2 \mathrm{mg} / \mathrm{MJ}$, calculated $1.4 \mathrm{mg} / \mathrm{MJ} ; \mathrm{Cu}$ analysed $0.2 \mathrm{mg} / \mathrm{MJ}$, calculated $0.2 \mathrm{mg} / \mathrm{MJ}$; Mn analysed $0.4 \mathrm{mg} / \mathrm{MJ}$, calculated $0.4 \mathrm{mg} / \mathrm{MJ}$.

\section{DISCUSSION}

The $\mathrm{Zn}$ intakes reported in the recent literature for mixed Western diets range from 8-18.6 mg/d (Guthrie \& Robinson, 1977; Holden et al. 1979; Lyon \& Smith, 1979; Milne et al. 1980) with the majority falling near the lower limit of this range and below the RDA for $\mathrm{Zn}$. It is possible that the RDA for $\mathrm{Zn}$ may be too high. Canadian university students consuming cafeteria meals received a mean $\mathrm{Zn}$ intake of $11.6 \mathrm{mg} / \mathrm{d}$ (Srivastava et al. 1977). This is slightly higher than the mean calculated $\mathrm{Zn}$ intake reported here $(10.1 \mathrm{mg} / \mathrm{d})$ but comparable to that recently calculated for post-menopausal, Canadian women $(11.0 \mathrm{mg} / \mathrm{d})$ (Anderson et al. 1981). Zinc intakes in this study were also highly correlated with protein intakes ( $r$ 0.739), a finding noted in earlier studies (Hunt et al. 1979; Anderson et al. 1981).

Calculated $3 \mathrm{~d}$ mean daily $\mathrm{Cu}$ intakes (mean $1.9 \mathrm{mg}$, range 0.9-4.0 mg) were comparable to recently reported values for North Americans consuming self-selected mixed diets (Holden et al. 1979; Milne et al. 1980) but below earlier estimates (Klevay, 1975). In general, the majority of the dietary $\mathrm{Cu}$ intakes were within the range of recently estimated adult $\mathrm{Cu}$ requirements from balance studies (Cartwright \& Wintrobe, 1964; Klevay et al. 1980). Low intakes of $\mathrm{Cu}$ were associated with low energy $(r 0.527)$ and low protein intakes $(r 0.412)$ 
compared to the CDS recommendations (Department of Health \& Welfare Canada, 1975), a finding also noted by Holden et al. (1979).

The mean $\mathrm{Mn}$ intake $(3.1 \mathrm{mg} / \mathrm{d})$ of these pre-menopausal women fell within the range (2-4 mg/d) reported in recent North American studies (Meranger \& Smith, 1972; Kirkpatrick \& Coffin, 1974; Srivastava \& Nadeau, 1978) and was lower than earlier estimates (Schroeder et al. 1966). These differences may be attributed in part to the increased use of refined cereals which are lower in $\mathrm{Mn}$ (Schroeder, 1971) than unrefined cereals; cereals being a major source of dietary $\mathrm{Mn}$. In this study, breads and cereals contributed $47 \%$ of dietary $\mathrm{Mn}$, and fruits $12 \%$ of dietary Mn. Tea is also a rich source (World Health Organization, 1973) and subjects with high $\mathrm{Mn}$ intakes (i.e. $>5 \mathrm{mg} / \mathrm{d}$ ) in this study consumed frequent cups of tea (World Health Organization, 1973).

There are major differences in the Se dietary intakes reported from several countries. This is attributed, in part, to varying levels of Se in the soil and hence dietary components, as well as differences in dietary patterns (Thomson \& Robinson, 1980). In Canada, the availability of foods originating from many different areas and supplementation of animal feeds with Se in North America alleviates any potential problems associated with soils low in Se (Morris \& Levander, 1970). Currently Se deficiency in human populations has not been described in North America. The calculated mean daily Se intake $(\mu \mathrm{g} / \mathrm{d})$ of the women in this study (131) was higher than those estimates for persons living in New Zealand (24), Italy (12.6), UK (60) and Japan (88-3) (Thomson \& Robinson, 1980) but comparable to the levels reported in Canadian Toronto mixed diets $(98-148 \mu \mathrm{g} / \mathrm{d}$; Thompson et al. 1975) and the estimated typical daily Se intakes in the USA (132 $\mu \mathrm{g} / \mathrm{d}$; Morris \& Levander, 1970). The dietary requirements for Se are not well established. At least three recent reports have described features characteristic of acute over-exposure to Se in man (e.g. Diskin et al. 1979; Van Hubbard et al. 1980). Hence, regular intakes of Se above the level of $200 \mu \mathrm{g} / \mathrm{d}$, received by nine of the subjects in this study, are probably undesirable if the risk of long-term chronic over-exposure is to be prevented. The major food sources of Se for these pre-menopausal women were meat plus substitutes $(38 \%)$ and bread plus cereals $(30 \%)$.

Both dietary fibre and phytate have been implicated in reducing the availability of $\mathrm{Zn}$ and possibly other trace elements in the diet (Oberleas \& Harland, 1977). In this study, animal products were the most important sources of dietary $\mathrm{Zn}$ and Se (Table 2) and dietary fibre intakes were within the range noted by others for subjects consuming mixed diets (Anderson et al. 1981; Marlett \& Bokram, 1981). It appears unlikely that absorption of trace elements from these mixed diets was adversely affected by dietary fibre and phytate.

The discrepancies between the analysed and calculated trace element intakes were not associated with inaccuracies in the laboratory analysis, as mean ( \pm SD) values obtained for the NBS Orchard Leaves compared very closely to the certified NBS values for $\mathrm{Zn}, \mathrm{Cu}$ and $\mathrm{Mn}$. Inadequate homogenity of the food composite was also not a source of error as $\mathrm{Zn}$, $\mathrm{Cu}$ and $\mathrm{Mn}$ analyses of four replicates of a selected $24 \mathrm{~h}$ food composite were comparable. Furthermore, losses of trace elements due to volatilization during the ashing procedure did not occur as recoveries were satisfactory. It is possible that subjects either failed to include certain foods and beverages in their $24 \mathrm{~h}$ food composite, or retained smaller portions for their $1 \mathrm{~d}$ food composite than were recorded in their food records. Alternatively, portion sizes for the record day were over-estimated. Certainly the comparable nutrient densities obtained for the analysed and calculated $\mathrm{l} d$ trace element intakes suggests that discrepancies in portion size, rather than omission of specific food items from the food composite, were responsible for the reported differences in the analysed and calculated $1 \mathrm{~d}$ trace element intakes. Greger et al. (1978) observed similar relative differences between analysed and calculated dietary $\mathrm{Zn}$ values determined from $51 \mathrm{~d}$ menus in two metabolic studies. However, their differences were apparently due to discrepancies in analysed $v$. food table values. 
Energy and selected nutrient intakes derived by calculation from the one record day set aside for the food composite collection, were also compared using a paired Student's $t$ test with mean intakes calculated from the other two record days. Differences were significant $(P<0.01)$ suggesting that energy and nutrient intakes on the day of the food composite collection were not representative of the other $2 \mathrm{~d}$. This suggests that when subjects were asked to reserve a duplicate portion of all foods and beverages consumed, their eating pattern was altered. White (1969) attributed the low energy intake of college women (18-30 years), determined by chemical analysis, to the collection of a $1 \mathrm{~d}$ food composite. In this study results suggest that chemical analyses of a $1 \mathrm{~d}$ food composite does not necessarily provide a more accurate assessment of dietary trace element intakes than those calculated from $3 \mathrm{~d}$ food records.

Notwithstanding the uncertainties associated with dietary information calculated from food records, it is clear from the results of this study that valuable information can be obtained using this methodology. The calculated and analysed trace element intakes when expressed on a per MJ basis were comparable, and the values from this study provide new information on the trace element intakes of Canadian pre-menopausal women consuming self-selected diets.

\section{REFERENCES}

Agriculture Handbook No. 8-1 (rev. 1976). Composition of Foods: Dairy and Egg Products, Raw-ProcessedPrepared. Agriculture Research Service. Consumer and Food Economics Institute, USDA.

Agricultural Handbook, No. 8-2 (rev. 1977). Composition of Foods: Spices and Herbs, Raw-Processed-Prepared. Agriculture Research Service. Consumer and Food Economics Institute, USDA.

Agriculture Handbook, No. 8-4 (rev. 1979a). Composition of Foods: Fats and Oils, Raw-Processed-Prepared. Agriculture Research Service. Consumer and Food Economics Institute, USDA.

Agriculture Handbook, No. 8-5 (rev. 1979 b). Composition of Foods: Poultry Products, Raw-Processed-Prepared. Agriculture Research Service. Consumer and Food Economics Institute, USDA.

Agriculture Handbook, No. 8-6 (rev. 1980a). Composition of Foods; Soups, Sauces and Gravies, Raw-ProcessedPrepared. Agriculture Research Service. Consumer and Food Economics Institute, USDA.

Agriculture Handbook, No. 8-7 (rev. 1980 b). Composition of Foods: Sausages and Luncheon Meats, RawProcessed-Prepared. Agriculture Research Service. Consumer and Food Economics Institute, USDA.

Allen, K. G. D., Klevay, L. M. \& Springer, H. L. (1977). Nutr. Rep int. 16, 227.

Anderson, B. M., Gibson, R. S. \& Sabry, J. H. (1981). Am. J. clin. Nutr. 34, 1042.

Arthur, D. (1972). J. Inst. Can. Sci. Techn. Aliment. 5, 165.

Cartwright, G. E. \& Wintrobe, M. M. (1964). Am. J. clin. Nutr. 14, 224.

Department of Health \& Welfare Canada (1975). Dietary Standard for Canada. Ottawa: Bureau of Nutritional Sciences, Health Protection Branch, Department of National Health \& Welfare.

Diskin, C. J., Tomasso, C. L., Alper, J. C., Glaser, M. L. \& Fliegel, S.E. (1979). Archs intern. Med. 139, 824.

Freeland-Graves, J. H., Ebangit, M. L. \& Bodzy, P. W. (1980). J. Am. diet. Ass. 77, 648.

Ganapathy, S. N., Joyner, B. T., Sawyer, D. R. \& Hafner, K. M. (1978). In Trace Element Metabolism in Man and Animals, Vol. 4, p. 322. Freising-Weihen-Stephan: Arbeitskreis fur Tierernahrungs-forschung Weihenstephan.

Greger, J. L., Marhefka, S., Huffman, J., Baliger, P., Peterson, T., Zaikis, S. \& Sickles, V. (1978). Nutr. Rep. int. 18, 345 .

Guthrie, B. \& Robinson, M. F. (1977). Br. J. Nutr. 38, 55.

Hambidge, K. M., Hambidge, C., Jacobs, M. \& Baum, J. D. (1972). Pediat. Res. 6, 868.

Holden, J. M., Wolf, W. R. \& Mertz, W. (1979). J. Am. diet. Ass. 75, 23.

Hunt, I. F., Murphy, N. J., Gomez, J. \& Smith, J. C. (1979). Am. J. clin. Nutr. 32, 1511.

Kirkpatrick, D. C. \& Coffin, D. E. (1974). J. Inst. Can. Sci Techn. Alliment. 7, 56.

Klevay, L. M. (1975). Nutr. Rep. int. 11, 237.

Klevay, L. M., Reck, S. J., \& Barcome, D. F. (1979). J. Am. med. Ass. 241, 1916.

Klevay, L. M., Reck, S. J., Jacob, R. A., Logan, G. M., Monoz, J. M. \& Sandstead, H. Y. (1980). Am. J. clin. Nutr. 33, 45.

Levine, R. A., Streeten, D. H. P. \& Doisy, R. J. (1968). Metabolism 17, 114.

Lyon, T. D. B. \& Smith, H. (1979). Br. J. Nutr. 42, 413.

Marlett, J. A. \& Bokram, R. L. (1981). Am. J. clin. Nutr. 34, 335.

Meiners, C. R., Derise, N. L., Lau, H. C., Crew, M. G., Ritchey, S. J. \& Murphy, E. W. (1976). J. agric. Fd Chem. 24, 1126

Meranger, J. C. \& Smith, D. C. (1972). Can. J. publ. Hlth 63, 53. 
Milne, D. B., Schnakenberg, D. D., Johnson, H. L. \& Kuhl, G. L. (1980). J. Am. diet. Ass. 76, 41.

Morris, V. C. \& Levander, O. A. (1970). J. Nutr. 100, 1383.

National Research Council, Food \& Nutrition Board (1980). Recommended Dietary Allowances (9th ed.). Washington, DC: National Academy of Sciences.

Oberleas, D. \& Harland, B. F. (1977). In Zinc Metabolism. Current aspects in Health and Disease, p. 11 [A. S. Prasad, editor]. New York: Alan R. Liss Inc.

Schlettwein-Gsell, D. \& Mommsen-Straub, S. G. (1971a). Int. Z. Vitam. Forsch. 40, 659.

Schlettwein-Gsell, D. \& Mommsen-Straub, S. G. (1971 b). Int. Z. Vitam. Forsch. 41, 269.

Schlettwein-Gsell, D. \& Mommsen-Straub, S. G. (1972). Int. Z. Vitam. Forsch. $42,607$.

Schroeder, H. A. (1971). Am. J. clin. Nutr. 24, 562.

Schroeder, H. A., Nason, A. P., Tipton, I. H. \& Balassa, J. J. (1966). J. chron. Dis. 19, 1007.

Southgate, D. A. T., Bailey, B., Collinson, E. \& Walker, A. F. (1976). J. human Nutr. $30,303$.

Srivastava, U. S. \& Nadeau, M. H. (1978). Nutr. Rep. int. $18,325$.

Srivastava, U. S., Nadeau, M. H. \& Carbonneau, N. (1977). J. Can. diet. Ass. 38, 302.

Thompson, J. N., Erdy, P. \& Smith, D. C. (1975). J. Nutr. 105, 274.

Thomson, C. D. \& Robinson, M. F. (1980). Am. J. clin. Nutr. 33, 303.

Van Hubbard, S., Barbero, G. \& Chase, H. P. (1980). J. Pediat. 96, 421.

White, H. S. (1969). J. Am. diet. Ass. 55, 38.

World Health Organization (1973). Tech. Rep. Ser. WHO no. 532. 